XXI. MEZINÁRODNÍ KOLOKVIUM O REGIONÁLNÍCH VĚDÁCH. SBORNÍK PŘ́́SPĚVKŮ.

\title{
21 ${ }^{\text {ST }}$ INTERNATIONAL COLLOQUIUM ON REGIONAL SCIENCES. CONFERENCE PROCEEDINGS
}

Place: Kurdějov (Czech Republic)

June 13-15, 2018

Publisher: Masarykova univerzita, Brno

\section{Edited by:}

Viktorie KLÍMOVÁ

Vladimír ŽÍTEK

(Masarykova univerzita / Masaryk University, Czech Republic)

\section{Vzor citace / Citation example:}

AUTOR, A. Název článku. In Klímová, V., Žítek, V. (eds.) XXI. mezinárodní kolokvium o regionálních vědách. Sborník příspěvkü. Brno: Masarykova univerzita, 2018. s. 1-5. ISBN 978-80-210-8969-3.

AUTHOR, A. Title of paper. In Klímová, V., Žítek, V. (eds.) $21^{\text {st }}$ International Colloquium on Regional Sciences. Conference Proceedings. Brno: Masarykova univerzita, 2018. pp. 15. ISBN 978-80-210-8969-3.

Publikace neprošla jazykovou úpravou. / Publication is not a subject of language check.

Za správnost obsahu a originalitu výzkumu zodpovídají autoři. / Authors are fully responsible for the content and originality of the articles.

(C) 2018 Masarykova univerzita

ISBN 978-80-210-8969-3

ISBN 978-80-210-8970-9 (online : pdf) 


\title{
HODNOCENÍ LIDSKÉHO POTENCIÁLU, EKONOMICKÉ A INOVAČNÍ VÝKONNOSTI V KRAJÍCH ČR
}

Evaluation of human potential, economic and innovation performance in regions of the Czech Republic

\section{LIBUŠE MĚRTLOVÁ}

\author{
Katedra ekonomických studií Department of economic study \\ Vysoká škola polytechnická Jihlava College of Polytechnics Jihlava \\ $\triangle$ Tolstého 16, 58601 Jihlava, Czech Republic \\ E-mail:mertlova@vspj.cz
}

\begin{abstract}
Anotace
Lidské zdroje, jejich počet a vzdělanostní struktura jsou předpokladem pro rozvoj inovačního potenciálu a následnè i ekonomické výkonnosti státu i jednotlivých regionů. Cílem článku bude na základě dostupných statistických dat analyzovat lidský, ekonomický a inovační potenciál krajů ČR v porovnání s Krajem Vysočina $V$ článku jsou použity metody komparace a analýzy dostupných dat zveřejňovaných Českým statistickým úřadem tak, aby bylo možné zvolené ukazatele a metody výpočtu použivat $i$ v následujicích letech pro provádění průběžného hodnocení podpory rozvoje a dalšího směřování dlouhodobých záměrü kraje. Na základě shromážděných dat je proveden výpočet potenciálu lidských zdrojů (dále LZ) a potenciálu ekonomické a inovační výkonnosti regionů (EIV), které jsou rozhodující pro zaměřní politiky regionálního rozvoje kraje. Nejlepší pozice lidského a inovačního potenciálu je v Hl. městě Praha, naopak nejhorší je Karlovarský kraj.
\end{abstract}

Klíčová slova

lidské zdroje, ekonomická a inovační výkonnost, potenciál regionu, regionální politika, strategie dlouhodobého rozvoje kraje

\section{Annotation}

The human resources, their number and the educational structure are a prerequisite for the development of the innovation potential and consequently the economic performance of the state and individual regions. The aim of the article will be to analyse the human, economic and innovation potential of the regions of the Czech Republic compared to the Vysočina Region based on available statistical data. The article uses methods of comparison and analysis of available data published by the Czech Statistical Office so that the selected indicators and calculation methods can be used in the following years to carry out the ongoing assessment of the development support and further direction of the long-term plans of the region. Based on the collected data, we make a calculation of the human resources potential $(H R)$ and the potential of the economic and innovation performance of the regions (EIP), which are decisive for the regional development policy of the region. The best positions of human and innovation potential are in the Capital City of Prague; on the contrary, the worst one is the Karlovy Vary region.

\section{Key words}

human resources, economic and innovation performance, regional potential, regional policy, long-term development strategy of the region

JEL classification: R11, R12, J21

\section{1. Úvod}

Základním předpokladem ekonomického rozvoje regionů je konkurenceschopnost, která slouží jako základní měřítko úspěšnosti firem, regionů i států. (Viturka, 2007) Regionální rozvoj a regionální konkurenceschopnost spolu úzce souvisejí. Ekonomický rozvoj je v tržních podmínkách jednoznačně spojen s pojmem konkurenceschopnosti jako základního měřítka dlouhodobé úspěšnosti firem, států, jejich regionů, měst i obcí. (Wokoun, Krejčová, 2013) Pouze region, který se rozvíjí, je schopný si svou konkurenceschopnost udržet. (Žítek, Klímová, Horká, 2013) Konkurenceschopnost regionů je dána jejich přírodními a geografickými podmínkami, 
dále historickým vývojem, zejména voblasti zemědělství a průmyslové výroby, dnes ale vstupují do konkurenceschopnosti regionů další faktory rozvoje, které většinou závisejí na vnitřních zdrojích, jako jsou lidské zdroje, jejich množství a vzdělanostní struktura a faktory inovačního potenciálu, jako rozsah, intenzita a struktura ekonomických aktivit a ekonomická a inovační výkonnost regionu. (Adviser-Euro, a.s., 2009) Podle Tvrdoně (2014) je potřeba výrazně orientovat aktivity v oblasti podpory regionálního rozvoje zejména na endogenní faktory regionů, na rozdíl od neoklasických přístupů a strategie pólů růstu, které se orientovaly na mobilitu faktorů a efektů lokalizace podniků v regionu, kdy jako zásadní nevýhody realizace těchto přístupů jsou uváděny zejména rozvoj potřeby práce s nízkými požadavky na kvalifikaci pracovní síly, lokalizace odvětví se standardizovanou výrobou a externí kontrolou, krátkodobé trvání vytvořených pracovních míst a jejich konjunkturální závislost a další. Regionální rozvoj se tak chápe v širším pojetí, ne pouze jako ekonomický růst, ale zejména i kvalitativní zlepšení struktury hospodářství, i životních podmínek. (Kožiak, 2008) Regionální konkurenceschopnost je v současné době podmíněna mnoha faktory, které se liší od tradičních faktorů, se kterými jsme byli zvyklí pracovat (dostupnost pracovní síly, dopravní náklady, suroviny), do hry vstupují faktory nové, jako jsou znalosti, inovace, kvalita lidských zdrojů, znalostní ekonomika a schopnost spolupráce mezi ekonomickými a dalšími subjekty ve společnosti. (Adviser-Euro, a.s., 2009) V důsledku těchto změn už konkurenční výhoda ve vyspělých zemích není dosahována prostřednictvím snižování nákladů (low-road strategie), ale především schopností inovovat a přinášet stále něco nového. (Dunning, 2000) Poněvadž v ČR hrají stále významnou roli tradiční ekonomické faktory regionálního rozvoje, je proto potřeba stále více rozvíjet a podporovat endogenní faktory rozvoje zaměřené na zvýšení ekonomického a rozvojového potenciálu území založeného na rozvoji lidských zdrojů, jejich vzdělanostní úrovni a rozvoji regionů jako center znalostí, tedy inovačních schopností firem, znalostní ekonomice a vědě a výzkumu. Rozvojem inovačních faktorů a mapováním lidského a inovačního potenciálu v ČR se zabývá řada domácích autorů, např. Kutscherauer a kol. (2010), Minařík a Dufek (2010), Wokoun, Krejčová (2013), Žítek, (2016), Winklerová, Žítek (2017), ze slovenských autorů lze jmenovat Tvrdoně (2014), Fázikovou (2011), Kožiaka (2016), Meričkovou Mikušovou, Mikuše, Muthovou, Kaščákovou (2017) a další. Dalším důležitým stupněm v rozvoji regionů je i zdůraznění role institucí, sociálního prostředí, vnitřních zdrojů regionu, atmosféry, etiky práce, spolupráci a efektivní vztahy v regionu. (Adviser-Euro, a.s. 2009, Spilková, 2004, Dušek (2015) Do popředí se dostávají strategie zaměřené na nové oblasti podnikání a zejména na průmyslová odvětví zaměřená na high-tech technologie. Roste zájem o vytváření partnerství, zejména ve veřejno-soukromé oblasti a vytváření industriálních klastrů a regionálních sítí (networks). (Tvrdoň, 2014)

\section{Cíl a metody}

Za hlavní složky ekonomického a rozvojového potenciálu regionů, determinující regionální konkurenceschopnost lze považovat následující skupiny charakteristik: lidské zdroje, ekonomickou a inovační výkonnost, rozsah, intenzitu a strukturu ekonomických aktivit, instituce a podporu podnikání, geografickou polohu, dopravní dostupnost a strukturu osídlení. (Viturka, 2007) Z této skutečnosti budeme vycházet i v př́spěvku, který se zaměřuje na první dvě skupiny a to na lidské zdroje a ekonomickou a inovační výkonnost.

V př́íspěvku vyjdeme z metodiky Adviser-Euro, a.s. z roku 2009 a to konkrétně z hodnocení LZ a EIV regionů ČR na úrovni NUTS III. Cílem příspěvku je informovat o provedené analýze těchto dvou hlavních faktorů regionální konkurenceschopnosti, které ji ovlivňují rozhodujícím způsobem a jejichž podpora z rozpočtů krajů a SR je v zájmu rozvoje regionů. Pro tyto účely jsou použita data z veřejné databáze Českého statistického úřadu a ze statistických ročenek krajů za rok 2016. Hlavními výsledky bude stanovení potenciálu LZ a EIV v jednotlivých regionech NUTS III v ČR a porovnání s potenciálem Kraje Vysočina. Na základě dosažených výsledků budou stanoveny závěry ve formě doporučení pro regionální politiku kraje.

\section{Analýza potenciálu lidských zdrojů}

Lidské zdroje chápeme jako klíčovou složku jak ekonomického potenciálu, tak zejména rozvojového potenciálu. Podle použité metodiky je budeme charakterizovat dvěma skupinami ukazatelů:

- demografickými ukazateli,

- ukazateli vzdělanostní struktury obyvatelstva.

Demografické ukazatele jsou založeny na charakteristice populace v regionu, tzn. na množství dostupné a využitelné pracovní síly, vývoji počtu obyvatel, věkové a vzdělanostní struktuře obyvatelstva regionu. Především věková struktura má vliv na sociální a zdravotní výdaje, i na potřeby školských a vzdělávacích zařízení, nemocnic, domovů pro seniory a dalších zařízení pro zabezpečení služeb pro obyvatelstvo v postproduktivním věku. Vzdělanostní struktura je předpokladem pro vznik nových pracovních příležitostí v sofistikovaných oborech, zvýšení podnikatelské aktivity obyvatelstva a přilákání investorů, což představuje zvýšení endogenního kapitálu území a zvyšování atraktivnosti regionu i z pohledu nabízených služeb v turistickém ruchu a dalších volnočasových služeb, přilákání zahraničních investorů, což představuje významné exogenní faktory. 


\subsection{Analýza potenciálu lidských zdrojů}

Je vyjádřena souhrnným ukazatelem, který zohledňuje dílčí ukazatele s tím, že některým dává větší váhu, protože mají větší vliv na potenciál LZ v regionu. Pro výpočet jel použit vzorec i váhy podle metodiky Adviser Euro a.s., který byl upravený na níže uvedený tvar, kdy ukazatele byly použity ze statistik ČSÚ s vlastním přepočtem na počet zaměstnaných v regionu u ukazatelů zaměstnanci ve $\mathrm{VaV}$, VŠ studenti, studenti VOŠ a výzkumných pracovníků. Váhy byly použity stejné jako v metodice, poněvadž vyjadřují názory expertů na různou důležitost jednotlivých ukazatelů vzhledem k celkovému lidskému potenciálu. Po provedeném výpočtu dostáváme počet bodů, kterými jsou ohodnoceny jednotlivé regiony a z nichž je následně stanoveno pořadí krajů.

$L Z k r a j=E A+M I G R+I S+3 * Z a m . V a V+2,5 * V \check{S}$ stud. $+1,5 * V O \check{S}$ stud. $+1,5 * V y ́ z k$. prac.

Popis využitých ukazatelů:

Podíl ekonomicky aktivních obyvatel na populaci regionu v \% (EA), je podíl zaměstnaných a nezaměstnaných (pracovní síly) k celkovému počtu osob 15letých a starších. Zdrojem dat je portál ČSÚ ČR, údaje jsou na úrovni krajů za rok 2016.

Intenzita migračního salda na 1000 obyvatel (MIGR) je definována jako rozdíl počtu přistěhovalých a vystěhovalých osob, vztažených na 1000 obyvatel regionu, data opět podle údajů ČSÚ. Přistěhovalí obyvatelé jsou v současnosti nejvýznamnějším faktorem dynamiky populačního vývoje.

Index stáří (IS) je konstruován jako podíl počtu osob nad 65 let k počtu osob 0 až 14 let v populaci. Vyjadřuje věkovou strukturu populace a náročnost na ekonomickou zátěž v této oblasti v souvislosti s poskytováním důchodů, zdravotních výdajů a potřeby zařízení pro seniory.

Počet zaměstnaných ve vědě a výzkumu (Zam. VaV) je ve výpočtu dán přepočtem počtu těchto zaměstnanců na 1000 zaměstnaných celkem v jednotlivých krajích. Charakterizuje vzdělanostní strukturu pracovních sil.

Počet studentů vysokých škol (VŠ stud.) je vztažený na 100 zaměstnaných obyvatel. Je vypočten jako podíl počtu vysokoškolských studentů v kraji a počtu zaměstnaných osob v kraji.

Počet studentů VOŠ (VOŠ stud.) je vztažený na 100 zaměstnaných obyvatel v krajích. Je vypočten jako podíl počtu studentů vyšších odborných škol a počtu zaměstnaných osob v kraji.

Zaměstnanci pracující ve výzkumu a vývoji (Výzk. prac.) Vyjadřuje podíl počtu výzkumných pracovníků v krajích na 1000 zaměstnaných osob v krajích, je jedním z významných indikátorů inovační schopnosti regionů.

Tab. 1: Výpočet potenciálu lidských zdrojů

\begin{tabular}{|c|c|c|c|c|c|c|c|c|c|}
\hline Ukazatel & EA & MIGR & IS & ZamVaV & VŠ stud. & VOŠ st. & Výz.prac & LZ kraj & Pořadí \\
\hline PHA & 62,8 & 10,3 & 122,4 & 33234 & 7176 & 1053 & 20325 & 149906 & 1. \\
\hline SČK & 61,1 & 9,1 & 101,5 & 10553 & 6044 & 328 & 4915 & 54805 & 4. \\
\hline JČK & 59,2 & 1,5 & 122,9 & 7659 & 7364 & 508 & 3107 & 46993 & 10. \\
\hline PZK & 60,7 & 3,5 & 126,7 & 9706 & 5519 & 602 & 5754 & 52639 & 5. \\
\hline KVK & 61,1 & $-3,5$ & 126,3 & 1398 & 4690 & 335 & 778 & 17773 & 14. \\
\hline ÚSK & 58,2 & $-1,8$ & 115,0 & 2516 & 5312 & 566 & 1175 & 23612 & 13. \\
\hline LBK & 59,0 & 2,3 & 118,4 & 10226 & 5665 & 151 & 4851 & 52524 & 6. \\
\hline KHK & 58,9 & $-1,1$ & 132,0 & 7520 & 6709 & 375 & 3528 & 45377 & 11. \\
\hline PAK & 60,5 & 1,8 & 122,5 & 9252 & 6494 & 543 & 4487 & 51721 & 8. \\
\hline VYS & 58,0 & $-1,0$ & 126,7 & 3952 & 7611 & 630 & 2115 & 35187 & 12. \\
\hline JMK & 60,4 & 3,2 & 122,9 & 22663 & 6634 & 525 & 14013 & 106567 & 2. \\
\hline OLK & 58,0 & $-1,3$ & 126,4 & 11377 & 7137 & 463 & 6719 & 62930 & 3. \\
\hline ZLK & 58,2 & $-1,7$ & 131,1 & 8329 & 7964 & 397 & 4298 & 52126 & 7. \\
\hline MSK & 59,3 & $-2,8$ & 124,5 & 7470 & 7404 & 501 & 4489 & 48587 & 9. \\
\hline Prům. & 59 & 1 & 123 & 4910 & 3301 & 232 & 2678 & 57196 & x \\
\hline
\end{tabular}

Zdroj: ČSÚ, vlastní zpracování

\section{Vyhodnocení potenciálu lidských zdrojů v krajích ČR}

Souhrnný ukazatel potenciálu LZ se pohybuje v hodnotách od 17773 bodů v Karlovarském kraji až k hodnotě 149906 bodů v Hlavním městě Praze. Je vidět veliká variabilita ukazatele v jednotlivých krajích (obr. 1), kdy aritmetický průměr souboru výsledného ukazatele potenciálu LZ má hodnotu 57196 bodů, směrodatná odchylka má hodnotu 32353 bodů a variační koeficient má hodnotu 56,56 \%. Nad průměrem souboru se pohybuje Hl. město Praha, Jihomoravský kraj a Olomoucký kraj. Nejvyšších hodnot ve všech ukazatelích mimo indexu stáří dosahuje region Hlavního města Prahy, bodová vzdálenost mezi Prahou a druhým nejsilnějším regionem Jihomoravským krajem predstavuje 43339 bodů. Jihomoravský region vyniká zejména v počtu pracovníků s vysokoškolským vzděláním, v počtu pracovníků ve výzkumu a v počtu vysokoškolských studentů. Na 3. místě je Olomoucký kraj, který dosáhl v hodnocení potenciálu LZ 62930 bodů. Tento region vyniká vysokým počtem 
zaměstnanců ve vědě a výzkumu, vysokým počtem vysokoškolských studentů a vysokým počtem zaměstnanců ve výzkumu. Pod průměrem souboru se umístily v rozmezí bodů 54805 až 51721 kraje v sestupném pořadí Středočeský (54805), s odstupem potom Plzeňský (52639), Liberecký (52524) a Zlínský (52126). Pod 50000 body jsou další 3 kraje a to Moravskoslezský (48587 bodů), Jihočeský (49993 bodů) a Královéhradecký (45377 bodů). Následuje Kraj Vysočina s 35187 body a poslední dva kraje Ústecký s 23612 body a Karlovarský s 17773 body.

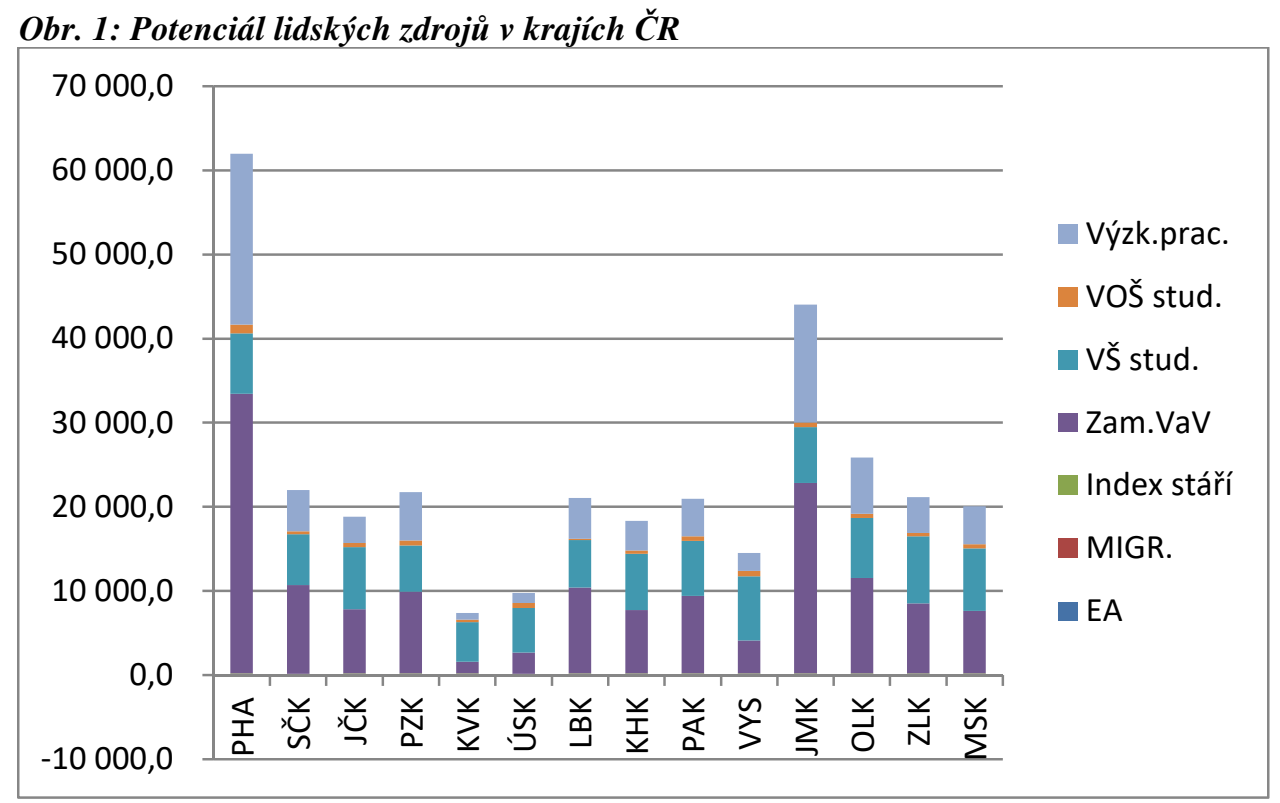

Zdroj: ČSÚ, vlastní zpracování

Kraj Vysočina má největší handicap v nízké ekonomické aktivitě a vysokém indexu stáří, zejména však v nízkém počtu zaměstnanců ve vědě a výzkumu a v počtu zaměstnanců ve výzkumu, kdy tyto ukazatele s vysokými vahami ve výpočtu výsledného potenciálu výrazně srážejí jeho pořadí. V počtu VŠ studentů se Kraj Vysočina umístil na 2. místě za Zlínským krajem a v počtu a studentů VOŠ je rovněž na 2. místě, hned za H1. městem Prahou. Je otázkou, zda absolventi těchto vzdělávacích zařízení nacházejí pracovní uplatnění v Kraji Vysočina, zda je zde dostatek pracovních př́ležitostí pro lidi s vysokoškolským vzděláním nebo zda musejí pracovní příležitosti hledat v ostatních krajích, zejména v H1. městě Praze a v Brně, které jsou z pohledu dopravních podmínek nejdostupnější. Doporučení pro zaměření Strategie pro roky 2020 plus v Kraji Vysočina je podpora pracovních př́ležitostí pro tyto absolventy, zejména v oblasti výzkumu a vývoje ve veřejném sektoru, kde se jeví výrazná potřeba posílit financování oblasti vědy a výzkumu s cílem zvýšení předpokladů rozvoje v oblasti ekonomické a inovační výkonnosti a využití lidského potenciálu absolventů z Vysočiny.

\subsection{Analýza ekonomické a inovační výkonnosti v krajích}

Mezi nejvýznamnější složky inovačního potenciálu patří ukazatele hrubého domácího produktu (HDP) a tvorba hrubého fixního kapitálu (THFK), které vyjadřují vnitřní produktivitu práce v regionu. HDP na obyvatele je nejdůležitějším ukazatelem makroekonomické výkonnosti, kdy vyjadřuje celkovou produktivitu práce, která je potenciálem pro růst celkového HDP regionu. Tvorba hrubého fixního kapitálu je zase předpokladem pro další růst produktivity práce, reálného HDP, rozvoj technologií a inovací. (Kahoun, 2007) Investice a tvorba nového hrubého fixního kapitálu jsou zárukou rozvoje a zvyšování dynamiky růstu rozvoje regionu založeného na zvyšování jeho hmotného i nehmotného potenciálu. Ukazatel hrubé přidané hodnoty (HPH) vyjadřuje efektivnost zhodnocení vložených zdrojů a generování nových hodnot v procesech probíhajících v regionu. Vyjadřuje sofistikovanost výrobních postupů a použitých technologií a zároveň i postavení pozice podniků v mezinárodní dělbě práce. Nízká přidaná hodnota odráží nízkou úroveň vkládané práce a naopak zastoupení odvětví s vyšším obsahem sofistikované práce v regionu generuje vyšší přidanou hodnotu a lepší postavení regionu v náročnějších oblastech práce. Ukazatel výdaje na $\mathrm{VaV}$ (VaV/ob.) vyjadřuje celkové výdaje vložené do sektoru vědy a výzkumu, které podporují rozvoj nových výzkumů, patentů, technologických postupů a sofistikovaných technologií v odvětvích náročných na kvalifikovanou lidskou práci. Ukazatel EIV vyjadřuje potenciál v oblasti ekonomiky a inovační výkonnosti v krajích, je vypočítaný podle následujícího vzorce:

EIV kraj $=3 * H D P / o b .+3 * H D P$ růst + THFK/ob. + HPH/ob. $+1,5 * V a V / o b .+2 * V P S+1,5 * Z a m . V a V$ 


\section{Popis využitých ukazatelů:}

HDP/ob. je statistický ukazatel ekonomické a inovační výkonnosti, potenciálu ekonomického růstu a životní úrovně. (vyjádřený v tis. Kč). Je čerpán ze statistiky regionálních účtů ČSÚ a je relativizován v přepočtu na obyvatele kraje.

HDP růst představuje meziroční nárůst sledovaného ukazatele vyjádřený v procentech. Vyjadřuje dynamiku změny základního ukazatele. Je čerpán ze statistik regionálních účtů ČSÚ.

THFK/ob. je ukazatel tvorby investic v regionu jak domácím, tak zahraničním kapitálem, v sektoru veřejném i soukromém.(vyjádřený v tis. Kč) Přepočet na obyvatele umožňuje srovnání krajů z hlediska jejich relativní komparace. Data jsou čerpána ze statistik regionálních účtů ČSÚ.

HPH/ob. vyjadřuje přidanou hodnotu v odvětvích $\mathrm{C}, \mathrm{G}, \mathrm{H}, \mathrm{I}, \mathrm{K}$ dle klasifikace odvětví CZ-NACE, kdy se jedná o odvětví s vyšší přidanou hodnotou (C - zpracovatelský průmysl, $\mathrm{G}$ - velkoobchod a maloobchod, $\mathrm{H}$ - doprava a skladování, I - ubytování a pohostinství, K - peněžnictví a pojištovnictví). (vyjádřený v tis. Kč) Data jsou pořízena z veřejné databáze ČSÚ.

Výdaje na VaV/ob. (VaV/ob.)vyjadřují celkové výdaje vložené do vědy a výzkumu v kraji přepočtené na obyvatele kraje, jsou v tisících Kč.

Výdaje podnikatelský sektor (VPS) představují výdaje na běžné i investiční náklady v soukromém podnikatelském sektoru. Data jsou čerpána z Veřejné databáze ČSÚ za rok 2016, údaje jsou v mil. Kč.

Zaměstnanci ve vědě a výzkumu (Zam.VaV) - ukazatel zahrnuje celkový počet fyzických osob pracujících v tomto sektoru v roce 2016, data jsou z Veřejné databáze ČSÚ podle jednotlivých krajů.

Tab. 2: Výpočet potenciálu ekonomické a inovační výkonnosti krajů

\begin{tabular}{|c|c|c|c|c|c|c|c|c|c|}
\hline Ukazatel & HDP/ob. & HDP růst & THFK/ob. & HPH/obyv. & VaV /ob. & VPS & Zam.VaV & EIV & Pořadí \\
\hline PHA & 937542 & 101 & 271214 & 317,0 & 21,71 & 12595 & 33519 & 3159961 & 1. \\
\hline SČK & 414379 & 105,9 & 108698 & 239,3 & 8,38 & 8199 & 8162 & 1381045 & 3. \\
\hline JČK & 373833 & 102,8 & 89260 & 80,0 & 4,46 & 1791 & 3591 & 1220122 & 9. \\
\hline PZK & 422251 & 103,2 & 89066 & 187,4 & 5,97 & 2458 & 4734 & 1368535 & 4. \\
\hline KVK & 300894 & 101,7 & 76957 & 62,1 & 0,58 & 168 & 264 & 992849 & 14. \\
\hline ÚSK & 333521 & 99,1 & 86648 & 373,4 & 1,05 & 566 & 1779 & 1081991 & 13. \\
\hline LBK & 352313 & 103,9 & 76689 & 97,2 & 6,03 & 2014 & 3241 & 1152896 & 12. \\
\hline KHK & 401056 & 105,2 & 90941 & 251,1 & 3,28 & 1268 & 3153 & 1287695 & 5. \\
\hline PAK & 360372 & 100,8 & 95683 & 170,4 & 4,90 & 2041 & 3662 & 1182111 & 10. \\
\hline VYS & 373421 & 103,3 & 85176 & 175,3 & 2,77 & 1284 & 1914 & 1221874 & 8. \\
\hline JMK & 436430 & 100,5 & 104789 & 413,5 & 12,72 & 8518 & 19939 & 1442145 & 2. \\
\hline OLK & 346789 & 102 & 84668 & 86,1 & 4,47 & 1382 & 4906 & 1155677 & 11. \\
\hline ZLK & 391336 & 103,3 & 92744 & 196,9 & 4,49 & 2184 & 3690 & 1269093 & 6. \\
\hline MSK & 385247 & 105,9 & 98971 & 396,6 & 4,25 & 3779 & 7321 & 1267743 & 7. \\
\hline Průměr & 416384 & 103 & 103679 & 210 & 6 & 2742 & 5104 & 1370267 & x \\
\hline
\end{tabular}

Zdroj: ČSÚ, vlastní zpracování

\section{Vyhodnocení potenciálu ekonomické a inovační výkonnosti}

Souhrnný ukazatel potenciálu ekonomické a inovační výkonnosti (EIV) se pohybuje v rozmezí 3159961 bodů v Hlavním městě Praze do 992849 bodů v Karlovarském kraji. Průměr ukazatele Potenciálu EIV má hodnotu 1370267 bodů, směrodatná odchylka souboru je 509528 bodů, variační koeficient má hodnotu 37,18\%. Nad průměrem souboru se umístily 3 kraje, Hl. město Praha, Jihomoravský a Středočeský. Hl. město Praha vyniká ve všech ukazatelích, zejména v ukazatelích inovační výkonnosti, a to v počtu pracovníků ve vědě a výzkumu, výdajích na vědu a výzkum i ve výdajích podnikatelského sektoru na vědu a výzkum. Co by bylo možné vytknout, je poměrně nízká dynamika růstu (101\%), ale patrně už to souvisí s efektem přetížení, kdy nové firmy hledají jiné místo pro své sídlo, investice a podnikání, což se projevuje v nejvyšším nárůstu indexu HDP ve Středočeském kraji a potom také v Moravskoslezském kraji. Na 2. místě se umístil Jihomoravský kraj, který představuje druhé jádro inovačního rozvoje v ČR, charakterizované vysokým počtem zaměstnanců ve vědě a výzkumu, vysokými výdaji na vědu a výzkum celkem i v podnikatelském sektoru, vysoké tvorbě hrubého fixního kapitálu a hrubé přidané hodnoty na obyvatele, která je dokonce vyšší než v Praze. Třetím krajem v pořadí je Středočeský kraj s druhou nejvyšší tvorbou hrubého fixního kapitálu, nejvyšší dynamikou nárůstu HDP, třetími nejvyššími výdaji na vědu a výzkum na obyvatele i s celkovými výdaji do VaV a třetím nejvyšším počtem zaměstnaných ve vědě a výzkumu. Těsně pod průměrem souboru se umístil Plzeňský kraj, s vysokým objemem HDP na obyvatele (dokonce vyšším než ve SČK), dobrým indexem růstu HDP, pátými nejvyššími výdaji na vědu a výzkum na obyvatele v ČR, silným zázemím v počtu pracovníků ve vědě a výzkumu. Jako slabší stránky v porovnání s ostatními kraji lze uvést nižší tvorbu hrubého fixního kapitálu na obyvatele, nižší hrubou přidanou hodnotu, což v porovnání s ostatními kraji signalizuje postupné zhoršování situace v potenciálu EIV. Následují 3 další kraje, které bychom mohli nazvat „tygry“ v oblasti zvyšování potenciálu v EIV. Jsou to kraje KHK, ZLK a MSK, které 
dosahují hodnoty od 1267753 bodů v MSK do 1287659 bodů v KHK. Charakteristická je pro ně vysoká tvorba HDP na obyvatele, vysoká a zhruba stejná tvorba THFK na obyvatele, vysoké tempo růstu HDP a vysoká HPH na obyvatele. Ve výdajích podnikatelského sektoru dominuje MSK, následovaný ZLK a KHK, kdy u těchto 2 krajů se výdaje podnikatelského sektoru na $\mathrm{VaV}$ podstatně snižují. Za těmito kraji následuje Kraj Vysočina s celkovým počtem 1221874 bodů a 8 . místem v pořadí krajů ČR. Za předchozími kraji zaostává ve výši HDP na obyvatele, dosahuje ale slušného tempa růstu a úrovně tvorby HPH na obyvatele. $\mathrm{V}$ počtu zaměstnanců ve vědě a výzkumu obsadil Kraj Vysočina 12. místo, stejně jako ve velikosti výdajů na vědu a výzkum celkem, v rámci výdajů podnikatelského sektoru do výzkumu a vývoje je na 10. místě. Podobný počet bodů 1220122 má JČK, který můžeme charakterizovat zejména nízkou hrubou přidanou hodnotou na obyvatele a nízkými výdaji na vědu a výzkum v podnikatelském sektoru. Následují 4 kraje s výslednými body ekonomické a inovační výkonnosti v rozmezí od 1089119 bodů v ÚSK do 1182111 v PAK. Patří sem ještě kraje OLK a LBK. Pardubický kraj z těchto krajů disponuje poměrně silnou tvorbou THFK a HPH na obyvatele, slušnými výsledky v inovačním potenciálu zaměstnaných pracovníků ve $\mathrm{VaV}$, výdajích na $\mathrm{VaV}$, avšak nízkým tempem růstu HDP. Další dva kraje, OLK a LBK, v pořadí 11. a 12. kraj, mají nízkou hodnotu THFK a HPH na obyvatele, kdy LBK má vyšší výdaje na VaV celkem i v podnikatelském sektoru, OLK zase disponuje větším počtem zaměstnanců ve vědě a výzkumu. Na předposledním 13. místě je ÚSK, který dosahuje záporného růstu HDP, a velmi nízkých ukazatelů ve VaV jak ve výdajích, tak v počtu pracovníků. Karlovarský kraj je poslední ve všech ukazatelích mimo tempa růstu HDP, v inovačních ukazatelích zaostává ve všech ukazatelích.

\section{Obr. 2: Potenciál ekonomické a inovační výkonnosti v krajích ČR}

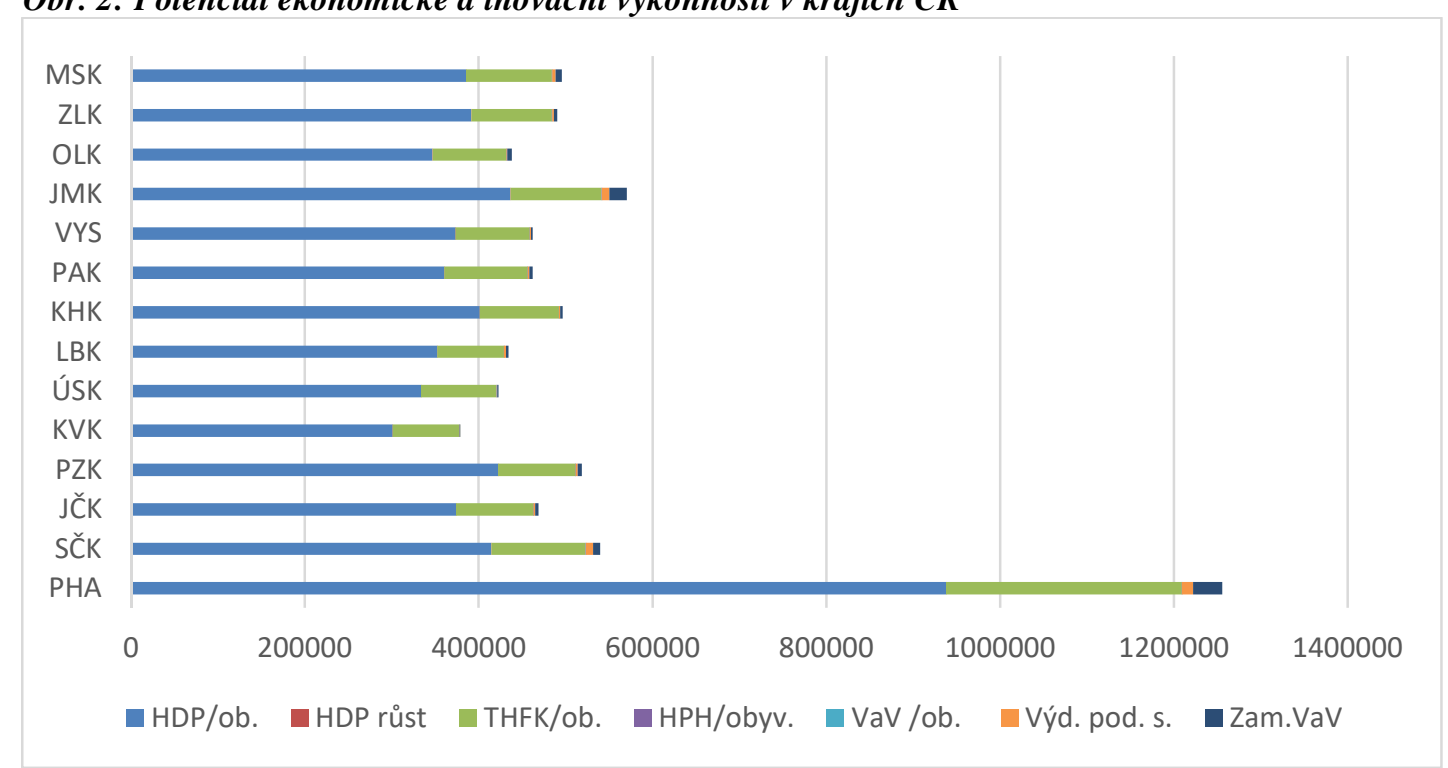

Zdroj: ČSÚ, vlastní zpracování

\section{Závěr}

Kraj Vysočina se umístil v potenciálu LZ na 12. místě, hluboko pod průměrem krajů bez Hl. města Prahy. Nejvyšší negativní hodnocení má kraj v oblasti ekonomicky aktivních obyvatel, indexu stáří, zaměstnanců ve vědě a výzkumu a v počtu výzkumných pracovníků, což sráží jeho potenciál LZ v oblasti inovačního potenciálu. Naopak nad průměrem souboru se pohybuje v počtu studentů VŠ a VOŠ, což do budoucna představuje značný potenciál pro rozvoj kraje, pokud se ho podaří využít. V oblasti EIV je kraj na 8. místě, těsně pod průměrem krajů bez HI. města Prahy. Kraj má podprůměrné výsledky v oblasti THFK/ob. a v HPH/ob., situace u HDP/ob. je poněkud lepší, kraj je těsně pod průměrem krajů bez Hl. města Prahy, u přírůstku HDP proti předchozímu roku je nad průměrem krajů. Znamená to, že nižší investice do THFK/ob. v budoucnu znamenají stagnaci výrobního potenciálu kraje a nižší generování ekonomických zdrojů pro rozvoj. Největší nedostatky jsou opět v ukazatelích inovačního potenciálu a to u výdajů na $\mathrm{VaV}$, výdajů podnikatelského sektoru do $\mathrm{VaV}$ a počtu zaměstnaných ve vědě a výzkumu. V oblasti rozvoje kraje v potenciálu EIV je možné jednoznačně doporučit zaměření na přilákání investorů do náročnějších odvětví s vyšší náročností práce, zejména v oblasti služeb v sektorech $\mathrm{G}, \mathrm{H}$, I a potom zvláště v sektoru K, kde je Vysočina na jednom z posledních míst. Realizace opatření zaměřených na tento cíl by zároveň mohla vést $\mathrm{k}$ vytvoření pracovních příležitostí pro uplatnění potenciálu stávající vzdělané pracovní síly v regionu i dnešních studentů a absolventů. Znamenalo by to posun k získání konkurenční výhody založené na znalostech a inovacích. Je to úkol pro vedení kraje, který zahrnuje i alokaci dostatečného množství finančních prostředků jak z fondů EU, tak i z prostř̌edků Kraje Vysočina. 


\section{Literatura}

[1] ADVISER-EURO, a.s., (2009). Metodika hodnocení ekonomického a rozvojového potenciálu území zpracovaná v rámci projektu Regionální ekonomická data pro evaluaci RPS a NSRR a pro sekundární analýzy regionálního rozvoje. Praha: MMR.

[2] ČESKÝ STATISTICKÝ ÚŘAD, (2018). Veřejná databáze. Regionální data v databázích ČSÚ. [online]. [cit. 2018-03-10]. Dostupné z: http:// www.vdb.czso.cz/.

[3] DUFEK, J., MINAŘÍK, B. (2010). Hodnocení rozvojového potenciálu krajů České republiky z hlediska lidských zdroju. Brno: MZLU. ISBN 978-80-7375-424-2.

[4] DUNNING, J. H., (2000). Regions, Globalisation and the Knowledge economy.The Issues Stated. In Regions, Globalisation and the Knowledge economy. New York: Oxford University Press, pp. 7-40.

[5] DUŠEK, J., (2015). Zahraniční spolupráce krajů ČR: Minulost, současnost, budoucnost. In XVIII. mezinárodní kolokvium o regionálních vědách. Sborník příspěvků. Brno: Masarykova univerzita, pp. 300305. ISBN 978-80-210-7861-1. DOI: 10.5817/CZ.MUNI.P210-7861-2015-60.

[6] FÁZIKOVÁ, M. a kol., (2011). Dimenzie znalostnej ekonomiky v Nitrianskom kraji. Nitra: SPU. ISBN 97880-552-0650-9.

[7] KAHOUN, J., (2007). Ukazatele regionální konkurenceschopnosti v České republice. Konkurenční výhoda české ekonomiky v oblasti high-tech aktivit. Working paper CES VEM. Praha: CES VŠEM, 2007, č. 5.

[8] KOŽIAK, R., (2008). Zmierňovanie regionálních disparít prostredníctvom regionálnej politiky. Banská Bystrica: UMB Banská Bystrica v spolupráci s OZ Ekonomika. ISBN 978-80-8083-573-6.

[9] KOŽIAK, R., SUCHÝ, M., CHOMJAKOVÁ, M., (2016). Využitie neoklasických predpokladov konvergencie pri analýze regionálných disparít. In XIX. mezinárodní kolokvium o regionálních védách. Sborník př́spěvki̊. Brno: Masarykova univerzita. pp. 59-64. ISBN 978-80-210-8273-1. DOI: 10.5817/CZ.MUNI.P210-8273-2016-36.

[10] KUTSCHERAUER, A. a kol., (2010). Regionální disparity. Disparity v regionálním rozvoji země, jejich pojetí, identifikace a hodnocení. Ostrava: VŠB-TU Ostrava. ISBN 978-80-248-2335-5.

[11] MERIČKOVÁ MIKUŠOVÁ, B., MIKUŠ, T., MUTHOVÁ, N., KAŠČÁKOVÁ, A., (2017). Hodnotenie inovačního potenciálu poskytovatelov verejných služieb - Ponuka verejných služieb. In XX. mezinárodní kolokvium o regionálních védách. Sborník př́spěvků. Brno: Masarykova univerzita. pp. 435- 449. ISBN 97880-290-8587-9. DOI: 10.5817/CZ.MUNI.P210-8587-2017-1.

[12] SPILKOVÁ, J., (2004). Kontaktní systémy, moderní aglomerační výhody a zahraniční investoři. Geografie -Sborník ČGS. 109, Č. 3, s. $252-265$.

[13] TVRDOŇ J., (2014). Od koncepcií lokalizácie k endogennému regionálnemu rozvoju. In XVII. mezinárodní kolokvium o regionálních védách. Sborník příspěvků. Brno: Masarykova univerzita, pp. $21-27$. ISBN 97880-210-6840-7. DOI: 10.5817/CZ.MUNI.P210-6840-2014-63.

[14] VITURKA, M., (2007). Regionální ekonomie a politika II. Brno: Masarykova univerzita.

[15] VITURKA, M., (2007). Konkurenceschopnost regionů a možnosti jejího hodnocení. Politická ekonomie, Praha: VŠE, 55, 5, s. 637-658, 22 s. ISSN 0032-3233.

[16] WINKLEROVÁ, L., ŽÍTEK, V., (2017). Inovační potenciál regionů jako zrcadlo ekonomické výkonnosti. In XX. mezinárodní kolokvium o regionálních vědách. Sborník př́spěvků. Brno: Masarykova univerzita, pp. 193 - 200. ISBN 978-80-290-8587-9. DOI: 10.5817/CZ.MUNI.P210-8587-2017-1.

[17] WOKOUN, R., KREJČOVÁ, N., (2013). Socioekonomická úroveň a faktory konkurenceschopnosti regionů v ČR. In XVI. mezinárodní kolokvium o regionálních vědách. Sborník příspěvků. Brno: Masarykova univerzita, pp. 30-41. ISBN 978-80-210-6257-3. DOI: 10.5817/CZ.MUNI.P210-6257-2013-3.

[18] WOKOUN, R. (2016). Základní problémy regionální konkurenceschopnosti a faktorů regionálního rozvoje v České republice. In XIX. mezinárodní kolokvium o regionálních vědách. Sborník př́spěvků. Brno: Masarykova univerzita, pp. 59-64. ISBN 978-80-210-8273-1. DOI: 10.5817/CZ.MUNI.P210-8273-2016-36.

[19]ŽÍTEK, V., KLÍMOVÁ, V., HORKÁ, L., (2013). Metodická úskalí regionální konkurenceschopnosti. Ekonomická revue, vol 16, no. 1, pp. 30-41. ISSN 1212-3951.

[20]ŽÍTEK, V., (2016). Změny zaměstnanosti ve výzkumu a vývoji v českých krajích. In XIX. mezinárodní kolokvium o regionálních vědách. Sborník př́spěvků. Brno: Masarykova univerzita, pp. 289-295. ISBN 97880-210-8273-1. DOI: 10.5817/CZ.MUNI.P210-8273-2016-36. 